\title{
主题公园驱动型的旅游度假区游客容量预测方法的探索 一以长兴图影度假区为例
}

\author{
Forecasting Method Exploration of Tourist Capacity in Driven Tourist Resort of Theme Park \\ - Taking Changxing Tuying Resort as an Example
}

\section{曾丽芸}

Liyun Zeng

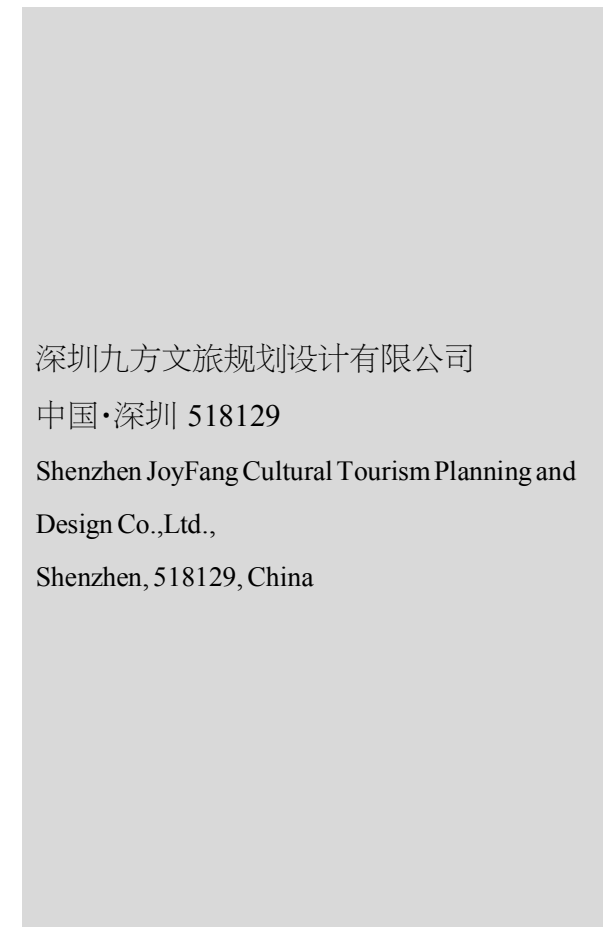

\section{1 引言}

2015 年底, 总投资 200 亿元的龙之梦乐园项目签约落户 长兴图影省级旅游度假区核心区域。2016 年 4 月,成功入选中 国优选旅游项目名录, 届时长兴图影省级旅游度假区旅游环境 发展发生了很大的改变。2016 年 11 月,太湖图影度假区管委 会要求根据龙之梦规划项目对太湖图影度假区旅游总体规划 进行局部调整,通过上位规划调整, 提供有效支撑促使龙之梦 项目顺利推进。因此,采用了常用的旅游地生命周期法与主题 公园的生命周期法结合的方式，首先对主题乐园类旅游度假 区游客量与主题乐园项目的游客量作了深入研究, 通过渗透 率法、案例比较法取平均值进行长兴图影度假区游客量预测。

\section{2 旅游地生命周期理论}

旅游地生命周期理论首先是由 Walter Christaller 提出, 目前, 由巴特勒 (Butler, 1980)提出的旅游地生命周期理论是 被学者们公认的,并广泛应用城市旅游目的地研究, 即根据旅
游目的地发展一般规律:即探索、参与、发展、巩固、停滞、分歧 等阶段,预判项目未来游客量 ${ }^{[1]}$ 。

长兴太湖图影旅游度假区旅游产品开发刚刚起步, 判断 项目进入参与阶段,如图 1 所示。

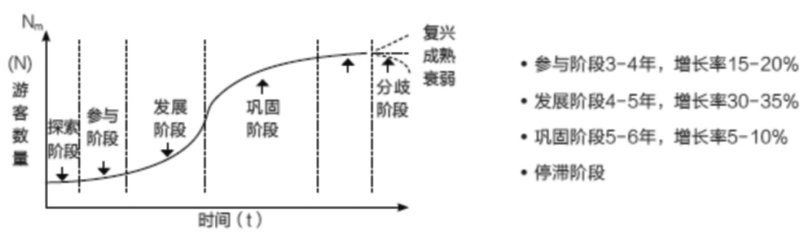

图 1 旅游地生命周期曲线图

\section{3 主题公园生命周期规律}

根据中国学者如保继刚、吴必虎等学者的研究得出主题 公园的生命周期演变不同于传统旅游地(资源), 探索、起步和 发展三个阶段都非常短暂 (甚至是交织在一起), 一般在正式 营业不久就快速转人巩固阶段, 此时会产生两种情况: (1)游客 量虽有一定的起伏, 但总体保持逐年递减的趋势, 开始步入停 
滞阶段; 2 游客量迅速下滑, 主题公园连年亏损, 最后倒闭 ${ }^{[2]}$ 。

其中龙之梦乐园规划 2019 年将整体建成开业, 预测龙之 梦将在 2019 年达到游客量接待增长峰值, 随后进入巩固阶 段,如图 2 所示。

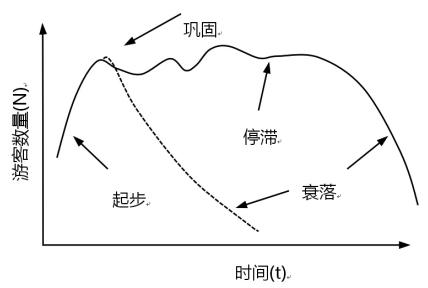

探索、起步和发展三个阶段都非常短暂(甚 至是交织在一起),一般在正式营业不久即 快速转入巩固阶段.

图 2 主题公园生命周期曲线图

\section{4 应用实例}

图影旅游度假区年游客量预测的关键点着重考虑 2019 年长峰人市对区域人流带来的变化。以下采用渗透率法和案 例比较法综合预测 2019 年人市的游客量。

\section{1 渗透率法}

长兴图影度假区旅游产品以生态旅游、休闲娱乐、健康疗 养等产品为主, 其中主题乐园项目规模最大, 选取广州长隆旅 游度假区、无锡天目湖旅游度假区及杭州湘湖旅游度假区来 进行类推对比, 预测得出度假区与度假区所在区县游客量渗 透率介于 46\% 58\% 之间 ${ }^{[3]}$ 。综合图影度假区及长兴县旅游产 品条件, 选取长兴县与图影度假区游客量渗透率为 $55 \%$, 具 体如表 1 所示。
州宋城公园、珠海的长隆海洋王国、北京欢乐谷以及上海迪斯 尼共 6 个国内较知名的旅游度假综合园区来进行类推对比。

根据现有主题公园的市场聚客力评估, 主题公园的游客 量通常在入市第一年就达到高值, 之后维持 5\% 8\% 的速率增 长, 预测结果如表 2 所示。

对表 2 类比结果取平均值: $(936+2559+1574+2677+$ $1122+2240) / 6=1850$ 万人次, 即龙之梦乐园开业后进入客流 稳定运营阶段, 2022 年预测客流量为 1850 万人次。

\section{表 2 案例比较法预测龙之梦乐园 2022 年客流量 (万人次)}

\begin{tabular}{|c|c|c|c|c|c|c|c|}
\hline $\begin{array}{c}\text { 类比旅 } \\
\text { 游区 }\end{array}$ & $\begin{array}{c}\text { 最大客 } \\
\text { 流量 } \\
\text { (万人) }\end{array}$ & $\begin{array}{l}\text { 景区面 } \\
\text { 积 }(\mathrm{Ha})\end{array}$ & $\begin{array}{l}\text { 开业 } \\
\text { 时间 }\end{array}$ & $\begin{array}{l}\text { 资源品 } \\
\text { 味修正 } \\
\text { 系数 }\end{array}$ & $\begin{array}{c}\text { 地理因 } \\
\text { 素修正 } \\
\text { 系数 }\end{array}$ & $\begin{array}{l}\text { 其他因 } \\
\text { 素修正 } \\
\text { 系数 }\end{array}$ & \begin{tabular}{|c} 
预测最 \\
大客流 \\
量
\end{tabular} \\
\hline $\begin{array}{l}\text { 长隆欢 } \\
\text { 乐世界 }\end{array}$ & 362 & 134 & 2006 年 & 1.15 & 0.9 & 2.5 & 936 \\
\hline $\begin{array}{c}\text { 常州恐 } \\
\text { 龙园 }\end{array}$ & 395 & 40 & 2000 年 & 1.8 & 1.2 & 3 & 2559 \\
\hline $\begin{array}{l}\text { 杭州宋 } \\
\text { 城公园 }\end{array}$ & 729 & 20 & 1996 年 & 1.2 & 0.9 & 2 & 1574 \\
\hline $\begin{array}{l}\text { 长隆海 } \\
\text { 洋王国 }\end{array}$ & 749 & 132 & 2014 年 & 1.3 & 1.1 & 2.5 & 2677 \\
\hline $\begin{array}{c}\text { 北京欢 } \\
\text { 乐谷 }\end{array}$ & 374 & 56 & 2006 年 & 1.5 & 0.8 & 2.5 & 1122 \\
\hline $\begin{array}{c}\text { 上海迪 } \\
\text { 斯尼 }\end{array}$ & 2000 & 700 & 2016 年 & 0.7 & 0.8 & 2 & 2240 \\
\hline $\begin{array}{c}\text { 龙之梦 } \\
\text { 乐园 } \\
2022 \text { 年 }\end{array}$ & \multicolumn{7}{|c|}{1851} \\
\hline
\end{tabular}

将以上度假区已有客流量与龙之梦乐园建成后吸引客流 量进行叠加, 得到龙之梦乐园 2019 年及 2022 年度假区总客

表 1 渗透率法预测度假区所在区县游客量渗透率

\begin{tabular}{|c|c|c|c|c|c|c|c|}
\hline 度假区 & 交通区位 & 规模 $\left(\mathrm{km}^{2}\right)$ & 度假区级别 & 核心产品 & \begin{tabular}{|c} 
游客量 \\
(万人次 $)$
\end{tabular} & \begin{tabular}{|c} 
所在区县游客 \\
量(万人次) \\
\end{tabular} & 渗透率 \\
\hline $\begin{array}{c}\text { 广州长隆旅游度 } \\
\text { 假区 }\end{array}$ & $\begin{array}{c}\text { 位于广州市番禺区,距 } \\
\text { 离广州市 } 18 \mathrm{~km}\end{array}$ & 29.74 & - & $\begin{array}{c}\text { 海洋世界、欢乐世界、 } \\
\text { 水世界、动物世界、旅 } \\
\text { 游度假酒店等 }\end{array}$ & $\begin{array}{c}1600(2015 \\
\text { 年) }\end{array}$ & $3502(2015$ 年) & $46 \%$ \\
\hline $\begin{array}{c}\text { 无锡天目湖旅游 } \\
\text { 度假区 }\end{array}$ & $\begin{array}{l}\text { 位于无锡市溧阳市 } 8 \text { 公 } \\
\text { 里,距离无锡市 } 107 \mathrm{~km}\end{array}$ & $\begin{array}{c}17.92 \\
\text { (含水域面积 } 7.25 \mathrm{~km}^{2} \text { ) }\end{array}$ & $\begin{array}{c}\text { 国家级旅游 } \\
\text { 度假区 }\end{array}$ & $\begin{array}{l}\text { 天目湖山水园、天目 } \\
\text { 湖水世界、天目湖南 } \\
\text { 山竹海、御水温泉等 }\end{array}$ & $\begin{array}{c}703(2014 \\
\text { 年) }\end{array}$ & 1341(2014 年) & $52 \%$ \\
\hline $\begin{array}{c}\text { 杭州湘湖旅游度 } \\
\text { 假区 }\end{array}$ & $\begin{array}{c}\text { 位于杭州市萧山区,距 } \\
\text { 离杭州市 } 20 \mathrm{~km}\end{array}$ & $\begin{array}{c}35 \\
\left(\text { 含水域面积 } 3.2 \mathrm{~km}^{2} \text { ) }\right.\end{array}$ & \begin{tabular}{|c} 
国家级旅游 \\
度假区
\end{tabular} & $\begin{array}{c}\text { 杭州乐园、烂苹果乐 } \\
\text { 园、杭州极地海洋世 } \\
\text { 界、金沙戏水、下村文 } \\
\text { 化村等 }\end{array}$ & $\begin{array}{c}1081(2015 \\
\text { 年) }\end{array}$ & $1880(2015$ 年) & $58 \%$ \\
\hline
\end{tabular}

对接《长兴县旅游业发展十三五规划(定稿)修订 12.12》, 选取长兴十三五规划 2019 年 1670 万人次作为依据, 按照 55\%渗透率计算, 得到 2019 年图影旅游度假区游客量为 919 万人次。

\section{2 案例比较法}

本项目根据龙之梦乐园的旅游定位, 以及所处地理位置及 发展规划等因素,选取了广州的长隆欢乐世界、常州恐龙园、杭
流量,如表 3 所示。

表 3 图影度假区近期总客流量预测

\begin{tabular}{c|c|c|c}
\hline 年份 & $\begin{array}{c}\text { 龙之梦项目流量 } \\
\text { (万人次/年) }\end{array}$ & $\begin{array}{c}\text { 龙之梦乐园游客量占度 } \\
\text { 假区游客量百分比 }(\%)\end{array}$ & $\begin{array}{c}\text { 度假区总流量 } \\
\text { (万人次/年 })\end{array}$ \\
\hline 2019 & 1450 & 90 & 1611 \\
\hline 2022 & 1850 & - & - \\
\hline
\end{tabular}

\section{3 综合法}

长兴太湖图影旅游度假区旅游产品伴随长峰集团龙之梦 
产业经济 Industrial Economy

项目的开发阶段, 判断项目 2019 年游客量达到峰值, 2020 年 开始进入巩固阶段。长兴太湖图影旅游度假区游客量如表 4 所示。

\section{表 4 旅游地阶段预测模型法预测度假区未来各年份游客量}

\begin{tabular}{|c|c|c|c|}
\hline 时间段 & 年份 & 游客量(万人) & 年增长率 \\
\hline \multirow{5}{*}{$\begin{array}{c}\text { 发展阶段-稳固 } \\
\text { 阶段 }\end{array}$} & 2019 & 1265 & \multirow{5}{*}{$5 \% \sim 8 \%$} \\
\hline & 2020 & 1370 & \\
\hline & 2021 & 1480 & \\
\hline & 2022 & 1600 & \\
\hline & 2023 & 1680 & \\
\hline \multirow{7}{*}{ 稳固阶段 } & 2024 & 1730 & \multirow{7}{*}{$3.00 \%$} \\
\hline & 2025 & 1780 & \\
\hline & 2026 & 1830 & \\
\hline & 2027 & 1880 & \\
\hline & 2028 & 1940 & \\
\hline & 2029 & 2000 & \\
\hline & 2030 & 2060 & \\
\hline
\end{tabular}

对以上类比结果取平均值: $(919+1611) / 2=1265$ 万人次, 即长峰人市开业后, 2019 年预测客流量为 1265 万人次。根 据主题公园项目旅游生命周期, 通常人市第一年达到较高值, 之后五年平均增长率在 $8 \%$ 左右,并逐年递减。

长兴太湖图影省级旅游度假区 2019 年、2022 年、2030 年 游客量分别为 1265 万人次, 1600 万人次、 2060 万人次。最终
得出的结论与预测 2030 年度假区游客量与龙之梦游客量预 测的 3000 万人次有所差别, 但相对来说比较合理, 同时床位 数规模与龙之梦规划酒店规模基本相符。由于游客量预测相 比于上一版本规划相差较大, 需要根据预测的游客量重新进 行市政数据的计算。

\section{5 结语}

本文通过对传统游客量预测方法的调整, 使之更适用于主 题乐园类的旅游度假区游客量预测, 并使用该方法对长兴图影 旅游度假区的游客量做出了预测。该预测方法的技术路线可 行, 但由于不同的旅游度假区特征差别较大, 在其他地区使用 该方法时, 仍需因地制宜地做出适当调整, 有待进一步研究。

\section{参考文献}

[1]王铁,邰鹏飞.山东省国家级乡村旅游地空间分异特征及影响 因素[J].经济地理, 2016(11):161-168.

[2]余瑞林,陈慧媛,陈广平,等.湖北省乡村旅游地空间分布及其影 响因素——以高星级农家乐为例[J].经济地理,2018(6):210-217.

[3]卢凤萍.南京市休闲农业空间差异及其社会经济影响因素分 析[J].中国农业资源与区划, 2017(11):231-236.

\section{（上接第 13 页）}

为了更准确地反映游客参观天后宫的次数与是否特地来 朝拜妈祖两者之间线性关系的强弱, 采用计算相关系数的方 法。由表可知游客参观天后宫与是否特地来朝拜妈祖的相关 系数为 0.313 , 所以二者存在这样一种关系,称为线性相关关 系, 其相关系数检验的概率 $P$ 值近似为 0 。所以, 当显著性水 平 $a$ 为 0.05 或 0.01 时, 应拒绝相关系数检验的原假设, 认为 两者不是零相关。

表 3 分析了旅游动机对重游意愿造成影响。

\section{表 3 旅游动机与重游意愿}

\begin{tabular}{c|c|c|c}
\hline \multirow{2}{*}{$\begin{array}{c}\text { 尔进行宗教旅 } \\
\text { 游主要是为了? }\end{array}$} & $\begin{array}{c}\text { 皮尔森(Perrson)相关显著性 } \\
\text { (双尾) }\end{array}$ & 1 & $0.235^{*}$ \\
\cline { 3 - 4 } & $\mathrm{N}$ & 116 & 0.11 \\
\hline \multirow{2}{*}{ 重游意愿 } & $\begin{array}{c}\text { 皮尔森(Perrson)相关显著性 } \\
\text { (双尾) }\end{array}$ & $0.235^{*}$ & \multirow{2}{*}{1} \\
\cline { 2 - 3 } & $\mathrm{N}$ & 0.011 & 116 \\
\cline { 2 - 3 } & \multicolumn{2}{|c}{116} \\
\hline
\end{tabular}

*.相关性在 0.05 上显著(双尾)。

由表可知, 旅游动机与重游意愿相关系数为 $0.235,|r|<3$ 说明这两种变量间的线性相关关系不强, 它的相关系数检验 的概率 $P$ 值近似为 0 。同上，当显著性水平 $a$ 为 0.05 或 0.01 时, 认为两总体不是零相关。

对上述结论进行分析后得出, 整体游客的重游意愿、推荐
意愿并不强, 说明多数乘客对沣洲岛的认知并不高, 而部分游 客愿意重游最主要因素是他们认可并欣赏沑洲岛自然风光。 因此需要考虑旅游者的认知价值和他们的满意度, 才能极大 的增强中国福建湄洲岛游客的行为意向。

\section{4 结语}

(1)本文通过被调查者的人口统计特征表显示湄洲妈祖庙 的主要客源地仍以莆田及台湾地区的人为主, 并且到访者多 为年纪偏大的人群。

(2)拓展妈祖文化信众基础最主要的因素是普通游客的观 光体验和宗教氛围。

(3)影响人们再次来访与朝拜妈祖的意愿的主要动机有五 个, 分别是朝拜妈祖、放松心灵、促进感情、观光游玩、汲取宗 教文化知识。

（指导教师:杨妮）

\section{参考文献}

[1]黄瑞国.妈祖学概论 [M].北京: 人民出版社, 2013.

[2]Reisinger Y. Tourism-Host Contact as Part of Cultural Tourism [J]. World Leisure and Recreation, 1994, 36:24-28.

[3]Jamiesion W. The Challenge of Cultural Tourism Canada.Tourism Bulletin [J]. ICOMOS Canada Bulletin, 1994,3(3):3-4. 